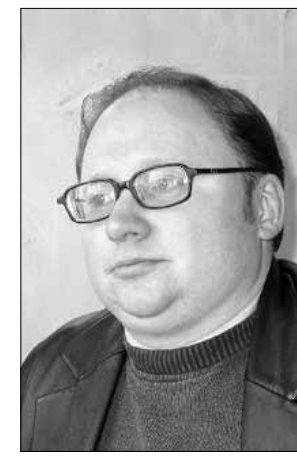

https://doi.org/10.24101/logos.2017.44

Vilniaus Gedimino technikos universitetas, Lietuva

Vilnius Gediminas Technical University, Lithuania

\title{
MOKSLŲ KLASIFIKACIJA, HIERARCHIJA IR SUBORDINACIJA SCHOLASTINĖJE MOKSLO TEORIJOJE
}

\author{
Classification, Hierarchy and Subordination of Sciences \\ in the Scholastic Theory of Science
}

\begin{abstract}
SUMMARY
This article analyses some of the most significant topics of scholastic theory of science, namely, classification, hierarchy and subordination of sciences. The author of the article focuses on theoretical sources as well as the criteria of those scholastic procedures. The article comes to the conclusion that scholastic theory of science took over the Aristotelian division of sciences into theoretical and practical ones, yet productive sciences lost the status of independent area of sciences within frames of above-mentioned theory. On the other hand, practical sciences were not unanimously given the status of real science. Within frames of the hierarchy of sciences, two cases of scientific priority were distinguished: a) according to the very nature of science; b) in respect of human cognition. Finally, the article captures two types of scientific subordination in scholastic theory of sciences: a) according to premises; b) according to objects.
\end{abstract}

\section{SANTRAUKA}

Straipsnyje nagrinėjamos vienos svarbiausių scholastinės mokslo teorijos temų: mokslų klasifikacija, hierarchija ir subordinacija. Straipsnio autorius susitelkia ties šių scholastinių procedūrų teorinėmis ištakomis ir kriterijais. Prieinama prie išvados, kad scholastinejje mokslo teorijoje perimtas aristotelinis mokslų skirstymas i teorinius ir praktinius, tačiau kūrybiniai mokslai neteko savarankiškos mokslų srities statuso. Kita vertus, pastebima, kad ne visi scholastai praktiniams mokslams priskyrè tikrojo mokslo statusą. Mokslų hierarchijos rẻmuose išskirti du vienų mokslų pirmumo kitų mokslų atžvilgiu atvejai: a) pagal pačią mokslų prigimti;; b) žmogiškojo pažinimo požiūriu. Galiausiai fiksuoti du mokslų subordinacijos, arba pavaldumo, atvejai: a) pagal mokslų prielaidas; b) pagal tiriamus objektus. 


\section{IVADAS}

Viena svarbiausių scholastinės mokslo teorijos temų buvo mokslu klasifikacija ir subordinacija. Čia buvo svarstomi tokie klausimai kaip mokslu tikslai, tiriami objektai, tyrimo principai ir metodai, mokslų tarpusavio santykiai etc. Pateikus atsakymus i minètus klausimus, buvo identifikuojama kiekvieno mokslo vieta scholastinëje žinijoje.

Kaip žinia, scholastika daugiausia buvo Aristotelio, jo daugiau ar mažiau nuosekliu pasekejjų ir komentatoriu filosofijos recepcija ir interpretacija. Lygiai taip pat ir scholastinė mokslo teorija ir mokslų klasifikacija bei subordinacija buvo kuriamos iš esmès remiantis ir interpretuojant Aristoteli. Šio straipsnio tikslas atskleisti esminius minètos interpretacijos bruožus. Šio tikslo siekiama remiantis iškiliais scholastinès mokslo teorijos Lietuvoje kūrèjais. Tai Senojo Vilniaus uni- versiteto ir Vilniaus jėzuitu kolegijos profesoriai - garsiosios Romos jèzuitu kolegijos auklètinis Martynas Smigleckis (Marcin Śmiglecki, Martinus Smiglecius, 1563-1618), Kordoboje ir Sevilijoje filosofinį ir teologinị išsilavinimą gavęs Jokūbas Ortizas (Diego Ortiz, Iacob Ortizius, 1564-1625) ir Alkalos universiteto absolventas Petras Viana (Pedro Viana, Petrus Viana, 1549-1609). Šio straipsnio autorius jau yra publikavęs keletą straipsniu, skirtų minètu scholastų mokslo teorijai. Tačiau tuose straipsniuose daugiausia dèmesio skirta scholastinèms kognityvinėms medijoms - irrodymui, apibrěžimui ir viduriniajam terminui. O šiame straipsnyje susitelkiama ties mokslų klasifikacijos, hierarchijos ir subordinacijos temo$\mathrm{mis}^{1}$. Jas nagrinejjant, daugiausiai taikomi analitinis - genealoginis ir lyginamasis doksografinis metodai.

\section{TEORINIAI IR PRAKTINIAI MOKSLAI}

Aristotelis mokslus skirste $i$ teorinius, praktinius ir poetinius, arba kūrybinius (sen. gr. poiesis - kūryba, kūrimas, darymas). Pagrindiniais teoriniais mokslais Aristotelis laikè fizika, arba gamtos filosofiją matematiką ir metafiziką. Pamatinių praktinių mokslų statusą jis priskyrè etikai ir politikai. O esminiais kūrybiniais mokslais laikyta retorika ir poetika. Svarbu pažymèti, kad pastarają Aristotelis suprato kaip bendrają visos kūrybos teoriją. Ypatingą statusą Aristotelis suteikè logikai, kurios nepriskyrè nè vienai iš minètų mokslų sričių. Logika kaip bendroji mąstymo ir protavimo teorija laikyta metodologiniu visu mokslų pagrindu - bendruoju instrumentu, taikomu tiek teoriniu, tiek praktiniu, tiek kūrybinių mokslų.

Scholastinė mokslų klasifikacija ne iki galo sekè Aristoteliu. Tiesa, perimtas mokslu skirstymas i teorinius ir praktinius, tačiau kūrybiniai mokslai prarado savarankiško mokslų poklasio statusą. Pats skirtumas tarp teorinių ir praktiniu mokslu aiškintas dvejopai. Pirma, šie mokslai skiriasi savo tikslais. Štai, pasak Ortizo, ,teorinio mokslo tikslas yra tiesa, tai yra grynas tiesos ir [to mokslo] objekto pažinimas, tuo tarpu praktinio moks- 
lo tikslas yra koks nors veikimas arba veikimo nukreipimas tinkama linkme“2. Taigi „teorinis mokslas yra tikslas savyje, kadangi vienintelis dalykas, kurio teorinis mokslas siekia, yra savojo objekto pažinimas “3. $\mathrm{O}$ šis pažinimas kaip tik ir tapatus mokslui. Tuo tarpu praktinis mokslas jau nebegali būti laikomas savitiksliu dalyku. Praktinis pažinimas visada turi tikslą už savęs paties. Tai vadovavimas kokiai nors žmogiškajai veiklai (mąstymui, elgesiui, valstybès valdymui, kūrybai etc.), arba formulavimas tam tikrų būtinų taisyklių, kurių ir tik kurių laikantis, toji veikla gali būti atliekama tinkamu būdu. Toks konkrečios žmogiškosios veiklos nukreipimas teisinga linkme negali būti tapatinamas su grynuoju tos veiklos pažinimu.

Kita vertus, teoriniai mokslai skiriasi nuo praktiniu savo objektais. Štai Ortizo teigimu, "teorinio mokslo objektas yra pats daiktas pagal savają prigimtí, tuo tarpu praktinio mokslo objektas yra daiktas, kiek jis yra mūsų pačių atliekamas ar ivykdomas ${ }^{\prime 4}$. Kitaip sakant, teorinio mokslo objektas - tai nuo mūsų veiklos nepriklausantis esinys, nagrinèjamas pagal esminius bei savybinius požymius (propria). Tuo tarpu praktinis pažinimas susitelkia ties kokia nors žmogiškaja veikla, kuri gali būti atliekama tiek gerai, tiek prastai, ir būtent dèl to reikia taisykliu ir dèsnių, kurie ją nukreiptu tinkama linkme. Tad praktinio mokslo objektu galime laikyti tinkamai atliekamą konkrečią žmogiškają veiklą (valstybės valdyma, mąstymą etc.).

Taigi sekdama Aristoteliu, scholastinè mokslo teorija skirste mokslus i teorinius ir praktinius. Kita vertus, palyginti su Stagyriečiu, scholastiniame mokslo diskurse ir mokslų klasifikacijoje kūrybiniai mokslai nebuvo išskiriami kaip savarankiška mokslų sritis. Ši skirtumą galima nesunkiai paaiškinti. Kūryba neabejotinai esanti viena žmogiškosios veiklos formų. Tad natūralu, jog scholastinèje žinijoje kūrybiniai mokslai nebuvo atskiriami nuo įvairias žmogiškąsias veiklas nagrinejjančiu ir nukreipiančiu praktiniu mokslu poklasio. Kita vertus, scholastinių mokslų klasifikacijoje pastebime dar vieną pokytị. Štai Aristotelis kūrybiniu mokslų srityje nebrèžè griežtos demarkacinès linijos tarp mokslo (scientia), meno ir amato (ars). Aristotelineje mokslu klasifikacijoje laivų statyba ir žemdirbystè laikyti tokiais pat kūrybiniais mokslais kaip retorika ir politika. Tuo tarpu scholastinejje mokslų klasifikacijoje nebeliko vietos menams ir amatams. İ šią klasifikaciją pateko tik tos žmogiškosios žinijos ir veiklos formos, kurios atitiko griežtą mokslo apibrèžimą: mokslas - tai būtinu esiniu pažinimas per būtinas ju priežastis. Tad nors scholastikoje retorika ir politika tapo praktiniais mokslais, laivu statyba ir žemdirbystė nebepateko i i šiu mokslų lauką ${ }^{5}$.

\section{AR IMANOMAS PRAKTINIS MOKSLAS?}

Kita vertus, ne visi scholastai laikèsi tradicinio mokslų skirstymo į teorinius ir praktinius. Kai kurie jų nesutiko praktiniams mokslams pripažinti tikrojo moks- linio pažinimo (scientia vera) statuso. Reprezentatyvus tokio atvejo pavyzdys yra Smigleckio mokslo teorija. Šio autoriaus teigimu, „būtinas mokslo požymis - pa- 
žinti daiktą tokị, koks jis yra pats savaime, o ne koks jis tampa dèl mūsų veikimo" ${ }^{\prime \prime}$. Tačiau „tik teorinis mokslas pažista daiktą pagal jo prigimtí, tuo tarpu praktinis mokslas pažìsta daiktą pagal jo santyki su [žmogiškaja veikla], todèl praktinis žinojimas yra mokslas tik antrine ir metaforine prasme ${ }^{\prime 7}$. Štai logika nesantis mokslas tikraja šio žodžio reikšme. Ji neanalizuoja trijų žmogiškojo mąstymo veiksmų (sąvokinio supratimo, teiginio ir samprotavimo) jų esminių požymių (giminès, rūšinio skirtumo, savybinio požymio (proprium) ir pan.) atžvilgiu. Iš tiesu logika pateikia taisykles ir dèsnius, kurie igalina minètus veiksmus atlikti tinkamai ir taisyklingai. Panašiai politika taip pat nèra mokslas tiesiogine prasme. Ji nenag- rinëja valstybės valdymo kaip tokio. Politika tesanti visuma taisyklių ir principų, kurių laikydamiesi valstybės valdymą paverčiame geru ir teisingu.

Taigi autentiško mokslo statusą Smigleckis priskyrè tik teorinio mokslo karalystei: matematikai, fizikai, metafizikai, muzikai, medicinai etc. O praktinès žinijos disciplinas (etika, politika, ekonomiką etc.) jis interpretavo kaip mokslų metaforas. Kaip minèta, tikrojo mokslo vardo Smigleckis nepripažino ir logikai. Tiesa, sekdamas Aristoteliu, jis logiką laikè bendruoju bet kokio mokslinio pažinimo įrankiu. Tačiau čia Smigleckio aristotelizmas ir baigèsi - bendrasis mokslų instrumentas nelaikytas mokslu tikraja šio žodžio prasme.

\section{MOKSLŲ HIERARCHIJA: KAS PIRMESNIS?}

Scholastinejje mokslo teorijoje daug dèmesio skirta mokslų hierarchijai. Ieškota kriteriju, pagal kuriuos hierarchijoje vienas mokslas būtų pirmesnis už kitą. Išskirti du esminiai tokio pirmumo atvejai - teigta, kad vienas mokslas gali būti pirmesnis už kitą (a) pagal savąąa prigimtí, arba natūraliąją daiktų tvarka, (b) pagal mus, t. y. žmogiškojo pažinimo požiūriu. Pastaruoju atveju pirmumas teikiamas mokslui, kurio prielaidos lengviau suprantamos ir labiau mums žinomos. Tad nenuostabu, kad „,tokiu [pirmumo] būdu matematika yra pirmoji iš visų [mokslų], kadangi ji išvedama iš jutimiškai akivaizdžių prielaidų ir negali būti paneigta" ${ }^{\prime 8}$. Taigi turima galvoje, kad matematika remiasi jutimiškai akivaizdžiomis, t. y. jusline iž̌valga, arba intuicija, suvokiamomis aksiomomis, iš kurių kildinamomis teoremomis galètu suabejoti nebent visiškas neišmanèlis. Ir būtent „dèl to Aristotelis tvirtina, kad vaikai gali suprasti matematika, bet ne fiziką" . Mūsų, arba žmogiškojo pažinimo, požiūriu vienas mokslas yra pirmesnis už kitą ir tada, kai pirmojo mokslo objekto pažinimas privalomas antrajam mokslui kaip būtina jo prielaida. Šiuo būdu fizika yra pirmesnè už metafiziką ,[fizika] tiria judèjima, dèl kurio metafizikoje atrandamos abstrakčios prigimtys "10. Čia akivaizdžiai turimas omenyje Dievo kaip pasaulio Pirmojo Judintojo irodymas (argumentum ex motu) - remiantis fizikoje nagrinejamu materialaus pasaulio daiktų ir reiškinių judejjimu, metafizikoje prieinama prie pirmųju, nematerialiu, šio judejimo priežasčių - Dievo ir jo tarpininkų angelų. 
Taigi žmogiškojo pažinimo požiūriu vienas mokslas gali būti pirmesnis už kitą pagal du kriterijus. Tuo tarpu pagal savają prigimtí, arba natūraliąją daiktų tvarka vienas mokslas būna pirmesnis už kitą jau pagal didesni kriteriju skaičių. Iškirtini keturi pagrindiniai tokios prigimtinès mokslinės pirmenybès atvejai:

A. Pirmojo mokslo objektas yra bendresnis už antrojo mokslo objektą. Pasak Smigleckio, „,bendresni dalykai jau pagal savają prigimti yra pirmesni už mažiau bendrus dalykus" ${ }^{11}$. Šiuo būdu pirmuoju iš visų mokslų laikyta scholastinès žinijos karalienè metafizika, tyrusi pati bendriausią objekta, koks tik gali būti būti kaip tokią.

B. Vienas mokslas yra subordinuotas, arba pavaldus (subordinatus sive subalternatus), kitam mokslui. Šis prigimtinio mokslinio pirmumo atvejis nusipelno atskiro aptarimo, todèl ji panagrinèsime paskutiniame straipsnio skyriuje.

C. Pirmojo mokslo objektas yra nepriklausomas nuo antrojo mokslo objekto, o antrojo mokslo objektas yra priklausomas nuo pirmojo mokslo objekto, kitaip sakant, pirmojo mokslo objektas yra būtina antrojo mokslo objekto sąlyga. Pasak Smigleckio, „šiuo būdu fizika pirmesnè už matematika, kadangi matematikos objektas yra priklausomas nuo fizikos - tai kiekybè, kuri yra fizinio kūno savybè ${ }^{\text {“12}}$. Turima galvoje, kad matematikos objektas kiekybè (skaičius, taškas, tiesė ir t. t.) realiai gali egzistuoti tik fizikos objekte - fiziniame, arba gamtiniame, kūne.

D. Vieno mokslo objektas pagal savo prigimti yra kilnesnis ir tobulesnis (nobilior perfectiorque) už kito mokslo objektą. Smigleckio teigimu, ,tokiu būdu metafizika yra pirmoji [tarp visų mokslų], kadangi ji yra [mokslas] apie Dievą ir inteligencijas"13.

Taigi akivaizdu, kad scholastinè mokslų hierarchija jokiu būdu nebuvo linijinè. Tai veikiau tam tikra spiralinio tinklinio pobūdžio sistema, kurioje pagal vienus kriterijus vieni mokslai yra pirmesni už kitus, tačiau pagal kitus kriterijus jau antrieji džiaugiasi pirmumo statusu. Štai mūsų, arba žmogiškojo pažinimo, atžvilgiu matematika pirmesnè už fizika, o pastaroji - už metafiziką. Tuo tarpu pagal savają prigimti minètieji mokslai išsidèsto priešinga seka. Čia pirmąją poziciją užima metafizika kaip visų mokslų karalienè, po jos eina fizika ir tik po šios - matematika.

\section{MOKSLŲ SUBORDINACIJA: KAS KAM PAVALDUS?}

Kaip minėta, scholastinejje mokslo teorijoje vienu esminių mokslinio pirmumo atvejų laikyta subordinacija, arba pavaldumas. Pagal ši pirmumo variantą mokslai skirstyti i subordinuojančius, arba valdančius (scientiae subordinantes sive subalternantes), ir subordinuotuosius, arba pavaldžius (scientiae subordinatae sive subaltarnatae). Skirtos dvi pagrindinès mokslų subordinacijos rūšys: a) pagal prielaidas; b) pagal tiriamus objektus. Pirmuoju atveju subordinuojančio mokslo prielaidos kartu yra ir subordinuotojo mokslo išvados. Šiuo būdu fizika yra pirmesnè už mediciną, nes medicinos prielaidos gaunamos fizikos moksle. Mat 
fizika tiria fizinį kūną (corpus physicum), o medicina nagrinèja sielą turinčio fizinio kūno (corpus physicum animatum) sveikatos sąlygas. Tad natūralu, kad medicina turi pradèti savo tyrimus nuo fiziniam kūnui kaip tokiam galiojančių dèsnių ir principu, kurie pateikiami fizikos mokslo išvadose. Tuo tarpu subordinacijos pagal tyrimo objektus atveju subordinuoto mokslo objektas yra tam tikra subordinuojančio mokslo objekto variacija pats valdančiojo mokslo objektas, igijęs atsitiktinį skiriamajji požymi (differentia accidentalis). Štai muzika subordinuota matematikai, kadangi jos objektas yra ne kas kita kaip skaičius, igijęs atsitiktini garso požymi (numerus sonorus).

Nagrinejjant mokslų subordinaciją pagal tyrimo objektus, keltas klausimas, ar pavaldus mokslas dar iki subordinacijos valdančiam mokslui disponuoja tikrojo mokslo statusu. I ši klausimą scholastinio mokslo teoretikai paprastai atsakydavo teigiamai. Štai Vianos tvirtinimu, „subordinuotas mokslas, dar prieš ji pajungiant subordinuojančiam [mokslui], nors ir nèra užbaigtas ${ }^{14}$, vis dèlto neabejotinai yra tikras mokslas (scientia vera) ir jo objektas - tai ne atsitiktinis, o savaiminis esinys, kurio kiekviena dalis yra šio mokslo nagrinejjama“"15. Taigi Viana laiko pavaldujji mokslą vertu tikrojo mokslo vardo, nes jis netiria atsitiktinès būties. Tiesa, subordinacijos pagal mokslų objektus atveju subordinuotojo mokslo objektas yra neatskiriamas nuo tam tikro atsitiktinio požymio. Tačiau pats subordinuotojo mokslo objektas jokiu būdu nèra atsitiktinè būtis. Tai tas pats subordinuojančio mokslo objektas, tik igijęs tam tikrą būdingą atsitiktini skiriamaji požymi, kai tuo tarpu atskiros subordinuojančio mokslo objekto rūšys priklauso jau nebe subordinuotam, o subordinuojančiam žinojimui ${ }^{16}$. Prisiminkime muzikos kaip matematikai pavaldaus mokslo atveji: muzikos objektas yra garsinị pavidalą igijęs skaičius, t. y. skaičius, turintis atsitiktini garsumo požymi, kuris muzikos objektą išskiria iš visų kitu skaičių. Taigi subordinuoto mokslo objektas nèra pats atsitiktinis požymis, arba akcidentas. Tai substancija, arba subjektas, igijęs atsitiktini požymį. Tokia substancija neabejotinai turi tam tikras būtinas savybes, kurias atskleidę ir išanalizavę ju priežastis pasiekiame tikraji mokslini žinojimą apie minètają substanciją. Toks žinojimas visiškai patenkina tikrajam mokslui keliamus reikalavimus - pasak Smigleckio, mokslas yra „akivaizdus intelektinis būtino esinio pažinimas per tikrają ir adekvačią to esinio priežastį ${ }^{\prime 17}$.

\section{IŠVADOS}

Scholastinëje mokslo teorijoje vienos svarbiausių temų buvo mokslų klasifikacija, hierarchija ir subordinacija. Kaip ir iš esmès visa scholastinè mokslo teorija, šios temos analizuotos Aristotelio mokslo teorijoje.
Scholastinè mokslo teorija perèmè aristotelini mokslų skirstymą $i$ teorinius ir praktinius. Tačiau scholastinëje mokslų klasifikacijoje kūrybiniai mokslai (poetika, retorika ir t. t.) neteko savarankiškos mokslų srities statuso. Čia jie nebu- 
vo atskiriami nuo įvairias žmogiškąsias veiklas nagrinejjančiu ir nukreipiančiu praktiniu mokslu poklasio. Kita vertus, ne visi scholastai laikèsi tradicinio mokslų skirstymo i teorinius ir praktinius. Kai kurie ju praktiniams mokslams nepripažino tikrojo mokslinio pažinimo statuso, laikè juos taisyklių ir instrukcijų rinkiniais i̇vairioms žmogaus veikloms, o ne daiktu pačių savaime tyrimais.

Sudarant mokslų hierarchija, ieškota kriteriju, pagal kuriuos vienas mokslas būtų pirmesnis už kitą. Išskirti du esminiai tokio pirmumo atvejai: a) pagal pačią mokslo prigimtį, arba natūraliąją daiktų tvarką; b) pagal mus, t. y. žmogiškojo pažinimo požiūriu. Tvirtinta, kad

\section{Literatūra ir nuorodos}

1 Vytis Valatka, Irodymas kaip medija scholastinèje mokslo teorijoje, Logos-Vilnius 80, 2014, p. 27-34; Vytis Valatka, Apibrěžimas kaip medija scholastinëje mokslo teorijoje, Logos-Vilnius 81, 2014, p. 62-69; Vytis Valatka, Vidurinysis terminas scholastinejje mokslo teorijoje: savarankška medija? Logos-Vilnius 81, 2015, p. 56-63.

2 Iacob Ortisius, In universam Aristotelis Logicam Summula. Vilnae, 1596 (Kraków: Biblioteka Jagiellońska, Rkps. 2080), folium 19.

3 Ten pat.

4 Ten pat.

5 Kita vertus, scholastinèje edukacijoje septyni laisvieji mokslai (gramatika, retorika, dialektika, aritmetika, geometrija, matematika ir astronomija) vadinti septyniais laisvaisiais menais (septem artes liberales).

6 Martinus Smiglecius, Commentaria in Organum Aristotelis (Vilnae, 1586-1587), ed. L. Nowak. Warszawa: Akademia teologii jezuickiej, 1987. Zeszyt 2, s. 184.

7 Ten pat.

8 Smiglecius, Commentaria..., s. 207. pirmuoju atveju mokslinę pirmenybę lemia didesnis tiriamo objekto bendrumo ir tobulumo laipsnis, to objekto savarankiškumas ir nepriklausomumas, galiausiai valdanti mokslo pozicija mokslu subordinacijos santykyje. Antruoju atveju pirmumą lemia mokslo prielaidu ir tiriamo objekto didesnis suprantamumas ir žinomumas.

Viena esminiu mokslinès pirmenybès pagal natūralią daiktų tvarką rūšių laikyta subordinacija. Pagal ši pirmumo variantą mokslai skirstyti i subordinuojančius, arba valdančius, ir subordinuotuosius, arba pavaldžius. Skirtos dvi pagrindinès mokslų subordinacijos rūšys: a) pagal prielaidas; $b$ ) pagal tiriamus objektus.

\footnotetext{
9 Ten pat.

10 Ten pat.

11 Ten pat.

12 Ten pat.

13 Ten pat. „Inteligencijų" terminas čia taikomas angelams, kurie kaip tobuliausi Dievo kūriniai neturi kūno ir yra grynosios protinès, arba intelektinès, būtybès, turinčios savyje aiškias ir ryškias Dieviškojo Proto idejjas ir perduodančios Dievo kaip pasaulio Pirmojo Judintojo impulsus žvaigždėms, planetoms ir kitiems kosminiams ir fiziniams kūnams.

14 Nèra užbaigtas, kadangi prieš pajungiant subordinuojančiam mokslui, jis pats savaime dar neturi savo esminių prielaidų, kurias perima iš subordinuojančio mokslo kaip jo išvadas.

15 Petrus Viana, Assertiones philosophicae ex praecipuis totius philosophiae Aristotelis difficultatibus. Vilnae, 1578 (Biblioteka Kórnicka, Cim. Qu. 2590), assertio 60 .

16 Smiglecius, Commentaria..., s. 206.

17 Ten pat, p. 182.
} 